\title{
Front Matter: Volume 9288
}

, "Front Matter: Volume 9288," Proc. SPIE 9288, Photonics North 2014, 928801 (25 September 2014); doi: 10.1117/12.2086140

SPIE. Event: Photonics North 2014, 2014, Montréal, Canada 


\title{
PROCEEDINGS OF SPIE
}

\section{Photonics North 2014}

\author{
Steve MacLean \\ David V. Plant \\ Editors
}

28-30 May 2014

Montréal, Canada

Organized by

Centre d'optique, photonique et laser, Université Laval (Canada)

CPIC-Canadian Photonics Industry Consortium (Canada)

INO-Institut National d'Optique (Canada)

Quebec Photonic Network (Canada)

Sponsored by

Sytacom (Canada)

Agilent Technologies (Canada)

CPIC-Canadian Photonics Industry Consortium (Canada)

Published by

SPIE 
The papers included in this volume were part of the technical conference cited on the cover and title page. Papers were selected and subject to review by the editors and conference program committee. Some conference presentations may not be available for publication. The papers published in these proceedings reflect the work and thoughts of the authors and are published herein as submitted. The publisher is not responsible for the validity of the information or for any outcomes resulting from reliance thereon.

Please use the following format to cite material from this book:

Author(s), "Title of Paper," in Photonics North 2014, edited by Steve MacLean, David V. Plant, Proceedings of SPIE Vol. 9288 (SPIE, Bellingham, WA, 2014) Article CID Number.

ISSN: 0277-786X

ISBN: 9781628413632

Published by

SPIE

P.O. Box 10, Bellingham, Washington 98227-0010 USA

Telephone +1 3606763290 (Pacific Time) · Fax +1 3606471445

SPIE.org

Copyright $@ 2014$, Society of Photo-Optical Instrumentation Engineers.

Copying of material in this book for internal or personal use, or for the internal or personal use of specific clients, beyond the fair use provisions granted by the U.S. Copyright Law is authorized by SPIE subject to payment of copying fees. The Transactional Reporting Service base fee for this volume is $\$ 18.00$ per article (or portion thereof), which should be paid directly to the Copyright Clearance Center (CCC), 222 Rosewood Drive, Danvers, MA 01923. Payment may also be made electronically through $\mathrm{CCC}$ Online at copyright.com. Other copying for republication, resale, advertising or promotion, or any form of systematic or multiple reproduction of any material in this book is prohibited except with permission in writing from the publisher. The CCC fee code is 0277-786X/14/\$18.00.

Printed in the United States of America.

Publication of record for individual papers is online in the SPIE Digital Library.

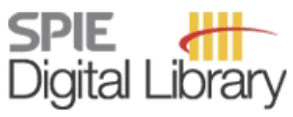

SPIEDigitalLibrary.org

Paper Numbering: Proceedings of SPIE follow an e-First publication model, with papers published first online and then in print and on CD-ROM. Papers are published as they are submitted and meet publication criteria. A unique, consistent, permanent citation identifier (CID) number is assigned to each article at the time of the first publication. Utilization of CIDs allows articles to be fully citable as soon as they are published online, and connects the same identifier to all online, print, and electronic versions of the publication. SPIE uses a six-digit CID article numbering system in which:

- The first four digits correspond to the SPIE volume number.

- The last two digits indicate publication order within the volume using a Base 36 numbering

system employing both numerals and letters. These two-number sets start with 00, 01, 02, 03, 04, $05,06,07,08,09,0 A, 0 B \ldots$. OZ, followed by 10-1Z, 20-2Z, etc.

The CID Number appears on each page of the manuscript. The complete citation is used on the first page, and an abbreviated version on subsequent pages. Numbers in the index correspond to the last two digits of the six-digit CID Number. 


\section{Contents}

vii Authors

ix Conference Committee

xi Introduction

HIGH POWER LASER TECHNOLOGY, ULTRAFAST OPTICS, AND APPLICATIONS

928802 A simple technique for accurate characterization of thermal lens in solid state lasers [9288-33]

NONLINEAR OPTICS, NANOPHOTONICS, AND QUANTUM OPTICS

928803 The effect of laser energy on $\mathrm{V}_{2} \mathrm{O}_{5}$ thin film growth prepared by laser assisted molecular beam deposition [9288-8]

\section{OPTICAL COMMUNICATIONS}

928805 An analytical XPM model for dispersion-managed fiber optic systems [9288-21]

928806 An efficient scheme of split-step Fourier method for fiber optic communication systems [9288-22]

928807 Flexible grid spacing using Nyquist-shaped channels for undersea transmission [9288-25]

928808 Performance evaluation of modulation format independent carrier phase estimation and decision directed carrier phase estimation for fiber non-linearity mitigation [9288-27]

928809 Investigation of a hybrid optical-electronic switch supporting different service classes [9288-38]

9288 OA Impact of hot temperature on end-face geometry of LC/UPC connectors [9288-39]

9288 OB Comparisons of LMS equalizers for PMD mitigation in polarization-multiplexed coherent fiber optic systems [9288-40]

9288 OC Long haul and high speed network using dual polarization two-band OFDM CS-NRZ-(D)QPSK signal [9288-46]

9288 OD Analysis of optical back propagation under non-ideal optical phase conjugation and amplifier noise [9288-53] 
$9288 \mathrm{OE}$ Analysis of the large and small signal direct current modulation response up to $60 \mathrm{GHz}$ of metal-clad nano-lasers [9288-10]

9288 OF Growth control of Ga(As)Sb quantum dots (QD) on GaAs with reflectance anisotropy spectroscopy (RAS) [9288-12]

9288 OG Challenge of inhomogeneous waveguides analysis [9288-15]

$9288 \mathrm{OH}$ Simulation of a metal nano-strip grating distributed Bragg reflector (DBR) Laser [9288-49]

\section{PHOTONIC COMMERCIALIZATION}

9288 Ol Optical response of large-area aluminum-coated nano-bucket arrays on flexible PET substrates [9288-1]

9288 0J Wide band fiber Bragg grating accelerometer for rotating AC machinery condition monitoring [9288-17]

\section{PHOTONIC MATERIALS}

9288 OK Band gap dependence upon thickness of chalcogenide Ge-As-S thin films [9288-34]

9288 OL Photoinduced GRIN lens formation in chalcogenide Ge-As-S thin films [9288-36]

$92880 \mathrm{M}$ Chemical vapor deposition of anisotropic ultrathin gold films on optical fibers: real-time sensing by tilted fiber Bragg gratings and use of a dielectric pre-coating [9288-37]

$9288 \mathrm{ON}$ Study of photo isomerization and photoinduced anisotropy of a mesogenic azobenzen dye mixture in various solid and liquid matrices [9288-45]

$928800 \quad$ High performance plafforms for integrated nonlinear optics [9288-58]

\section{PHOTONIC SENSORS AND BIOMEDICAL OPTICS}

9288 OP Ex-vivo multi-modal microscopy of healthy skin [9288-2]

$92880 Q$ Photoacoustic imaging of an inflammatory lesion model in the neonatal rat brain [9288-3]

9288 OR MRI-guided fiber-based fluorescence molecular tomography for preclinical atherosclerosis imaging [9288-6]

9288 OS An improved method of measuring heart rate using a webcam [9288-7]

9288 ОT Femtosecond laser induced fiber Bragg gratings for harsh environment sensing applications [9288-13] 
9288 OU Silicon photonics characterization platform for gyroscopic devices [9288-28]

9288 OV Design and finite element modeling of a novel optical microsystems-based tactile sensor for minimal invasive robotic surgery [9288-29]

9288 OW Strategies for leukemic biomarker detection using long-range surface plasmon-polaritons [9288-43]

$92880 X \quad$ Near-infrared spectroscopy of image clarity perception in the human brain [9288-44]

9288 OY Resonance structure of quantum-dot-coated microspheres for microfluidic sensing [9288-47]

$92880 Z$ Plasmonic properties of suspended nanodisc structures for enhancement of the electric field distributions [9288-54]

928810 Analysis of mode transitions in a long-period fiber grating with a nano-overlay of diamondlike carbon [9288-55]

PHOTONIC THEORY, DESIGN, AND SIMULATIONS

928811 Analysis of $\mathrm{Yb}^{3+} / \mathrm{Er}^{3+}$-codoped microring resonator cross-grid matrices [9288-16]

928812 Theoretical sensitivity analysis of quadruple Vernier racetrack resonators designed for fabrication on the silicon-on-insulator platform [9288-18]

928813 Roles of high order bending modes in optical wave coupling [9288-23]

928814 Spoof plasmons in real metals with an arbitrary shape of perforation [9288-24]

928815 A novel silicon nitride slot waveguide [9288-32]

928816 Investigation of mode partition noise in Fabry-Perot laser diode [9288-48]

928817 Advances in silicon photonics segmented electrode Mach-Zehnder modulators and peaking enhanced resonant devices [9288-56]

928818 Accelerated simulation of optical coherence tomography of objects with arbitrary spatial distributions [9288-59]

PLASMONICS, HYBRID PLASMONICS, AND ARTIFICIAL MEDIA

928819 Surface plasmon enhanced optoelectronics [9288-57]

$92881 \mathrm{~A} \quad$ Effect of symmetry breaking and substrate on the optical properties of silver sphere-like nanoparticles in different surrounding media [9288-62] 
Proc. of SPIE Vol. $9288928801-6$

Downloaded From: https://www.spiedigitallibrary.org/conference-proceedings-of-spie on 26 Apr 2023 Terms of Use: https://www.spiedigitallibrary.org/terms-of-use 


\section{Authors}

Numbers in the index correspond to the last two digits of the six-digit citation identifier (CID) article numbering system used in Proceedings of SPIE. The first four digits reflect the volume number. Base 36 numbering is employed for the last two digits and indicates the order of articles within the volume. Numbers start with 00, 01, 02, 03, 04, 05, 06, 07, 08, 09, OA, OB...0Z, followed by 10-1Z, 20-2Z, etc.

\begin{tabular}{|c|c|}
\hline Abdel Samad, B., 03 & Hohertz, Donna, Ol \\
\hline Abumazwed, A., $\mathrm{OZ}$ & Huang, Wei-Ping, 13, 16 \\
\hline Albert, Jacques, $0 M$ & Jaeger, Nicolas A. F., OU, 12 \\
\hline Almarghalani, Maan, OU & Joress, Howie, OM \\
\hline Alsawafta, Mohammed, IA & Kavanagh, Karen L., Ol \\
\hline Ashrit, P. V., 03 & Kirk, A. G., OZ \\
\hline Barry, Seán T., OM & Koba, M., 10 \\
\hline Bellec, Pierre, $0 Q$ & Krupin, O., OW \\
\hline Berini, Pierre, OW, 19 & Kumar, Shiva, 05, 06, OB \\
\hline Berti, Romain, $\mathrm{OQ}$ & Kung, Peter, OJ \\
\hline Bock, Wojtek J., 10 & Landrock, Clint, Ol \\
\hline Boeck, Robert, 12 & Lepers, Catherine, OC \\
\hline Brabant, D., 10 & Lesage, Frédéric, $\mathrm{OP}, \mathrm{OQ}, \mathrm{OR}$ \\
\hline Cada, M., OG, 14 & Li, Baoqiang, OR \\
\hline Castonguay, Alexandre, $\mathrm{OP}$ & $\mathrm{Li}, \mathrm{J} ., 07$ \\
\hline Caverley, Michael, oU & $\mathrm{Li}, \mathrm{Xun}, 13,16$ \\
\hline Chaichok, Wasan, OA & Liang, Haibo, 13, 15 \\
\hline Chen, Lawrence R., OD & Liang, Xiaojun, 05, 06, OB \\
\hline Chrostowski, Lukas, OU, 12 & Lima, Ivan T., 18 \\
\hline Chuo, Yindar, Ol & Liv, Yi, OS \\
\hline Comanici, Maria I., OJ & Lodygensky, G. A., OQ \\
\hline Cretu, Edmond, OU & Loeber, Thomas H., OF \\
\hline Deng, Lanxin, $\mathrm{OH}, 15,16$ & Londono, Irène, $0 Q$ \\
\hline Ding, H., OT & Lourdiane, Mounia, 09, 0C \\
\hline Ding, Qiudi, OB & LU, P., OT \\
\hline Djurovic, Sinisa, 0J & Lugo, J. E., OX \\
\hline Doti, Rafael, OX & Major, A., 02 \\
\hline Eldlio, M., OG & Malektaji, Siavash, 18 \\
\hline Escobar I., Mauricio R., 18 & Mandia, David J., OM \\
\hline Faubert, Jocelyn, OX & Manjooran, S., 02 \\
\hline Fazel, Sina, $0 C$ & Mehta, P., 07 \\
\hline Fouckhardt, Henning, OF & Meldrum, A., OY \\
\hline Gălătuş, Ramona, 11 & Merget, F., 17 \\
\hline Galstian, T., OK, OL, ON & Mihailov, S. J., ОТ \\
\hline Gaudette, J., 07 & Minasyan, A., ON \\
\hline Ghanbari Mardasi, Amir, OV & Mirzaeian, H., 02 \\
\hline Ghanbari, Mahmood, OV & Morandotti, Roberto, 00 \\
\hline Giorgi, Javier B., OM & Moss, David J., 00 \\
\hline González, Francisco Javier, OP & Mu, Jianwei, $\mathrm{OH}, 13,15,16$ \\
\hline Gordon, Peter, OM & Müller, J., 17 \\
\hline Gric, T., OG, 14 & Omrane, Badr, Ol \\
\hline Grobnic, D., ОT & Ouyang, Jianfei, OS \\
\hline Guevara, Edgar, OP, OQ & Pakala, Lalitha, 08 \\
\hline Guillén-Torres, Miguel Ángel, OU & Palanjyan, K., OK, OL \\
\hline Guo, Qingyi, OH, 15, 16 & Pouliot, Philippe, OR \\
\hline Gutiérrez-Hernández, José Manuel, OP & Rezagholipour Dizaji, Mohammad, OD \\
\hline Habak, C., OX & Richter, Johannes, OF \\
\hline
\end{tabular}


Romero-García, S., 17

Salmani Tehrani, Mehdi, OV

Samoud, Wiem, 09

Sarraf, Elie H., OU

Sattar, Z. A., OE

Scepanovic, S., OJ

Schmauss, Bernhard, 08

Shao, Jing, 06

Sharif Azadeh, S., 17

Shen, B., 17

Sherif, Sherif S., 18

Shore, K. Alan, OE

Smietana, Mateusz, 10

Smith, Alexander C., OJ

Strassner, Johannes H., OF

Thongdaeng, Rutsuda, OA

Tork, A., ON

Truong, Vo-Van, IA

Tshiloz, Kavul, OJ

Vallée, R., OK, OL

Vallés, Juan A., 1

Vilchis-Rodriguez, Damian S., OJ

Wahbeh, Mamoun, 1A

Walker, R. B., OT

Wang, C., OW

Wang, Guanhui, OD

Wangsan, Sathit, OA

Ward, Matthew J., OM

Ware, Cédric, 09

Wartak, M. S., 14

Witzens, J., 17

Worasucheep, Duangrudee, OA

Xie, Ningshi, $0 Q$

Yan, Yonggang, OS

Zhi, Y., OY

Zhou, Wenjun, OM 


\title{
Conference Committee
}

\author{
Conference Chairs
}

Steve MacLean, INRS-EMT (Canada)

David V. Plant, McGill University and SYTACom (Canada)

Vice Chairman

George A. Lampropoulos, A.U.G. Signals (Canada)

Technical Program Chairs

Roberto Morandotti, INRS (Canada)

Stewart Aitchison, University of Toronto (Canada)

Session Chairs

1 Green Photonics, Energy, and Related Technologies

Winnie Ye, Carleton University (Canada)

2 High Power Laser Technology, Ultrafast Optics, and Applications

Donna Strickland, Waterloo University (Canada)

3 Nonlinear Optics, Nanophotonics, and Quantum Optics

Luca Razzari, INRS-EMT (Canada)

4 Optical Communications

Raman Kashyap, École Polytechnique de Montréal (Canada)

5 Optoelectronics and Integrated Optics

Amr Helmy, University of Toronto (Canada)

6 Photonic Commercialization

Peter Kung, QPS (Canada)

7 Photonics Materials

Peter Hermann, University of Toronto (Canada)

8 Photonic Sensors and Biomedical Optics

Al Meldrum, University of Alberta (Canada) 
9 Photonics Theory, Design, and Simulation

Pavel Cheben, National Research Council Canada (Canada)

10 Plasmonic, Hybrid Plasmonics, and Artificial Media Mo Mojahedi, University of Toronto (Canada) 


\section{Introduction}

Photonics technologies have become pervasive and contribute to many different sectors including communications, sensing, displays, and lighting. It is in this context that Montreal welcomes the Canadian and International Photonics communities to its annual premier event: Photonics North 2014.

Researchers will share their latest results and innovations. The programming includes a collection of plenary, invited, and contributed talks as well as a commercial exhibit will allow several Canadian and foreign suppliers of photonic technology and instrumentation to showcase their products.

On behalf of the entire Program Committee, we welcome you to Photonics North.

David V. Plant

On behalf of the organizing committee for Photonics North 2014 I would like to welcome you to the "Palais des Congrès" in Montreal for the 17th annual Photonics North Conference. We have an exciting conference covering topics ranging from the fundamental interaction of photons with matter to practical sensors for a variety of useful applications.

Sessions this year include: Optical Communications; Optoelectronics and Integrated Optics; Photonics Materials; Nonlinear Optics, Nanophotonics and Quantum Optics; Photonic Sensors and Biomedical Optics; Photonic Commercialization; Photonic Theory, Design, and Simulation; Plasmonic, Hybrid Plasmonics, and Artificial Media; High Power Laser Technology, Ultrafast Optics, and Applications; and Green Photonics, Energy, and Related Technologies.

We are fortunate to have a large group of experts (including your colleagues and friends) coming together in a venue that is conducive to fostering new ideas and integrating innovative concepts across disciplines. The conference is committed to a high standard of excellence and we promise that you will agree that the bar has been raised again this year.

Enjoy Photonics North 2014!

Steve MacLean 
Proc. of SPIE Vol. $9288928801-12$

Downloaded From: https://www.spiedigitallibrary.org/conference-proceedings-of-spie on 26 Apr 2023 Terms of Use: https://www.spiedigitallibrary.org/terms-of-use 